\title{
The Movement Toward a Monolingual Nation in Russia: The Language Policy in the Circassian Republics of the Northern Caucasus
}

\author{
Sufian Zhemukhov ${ }^{*}$ \\ Şener Aktürk ${ }^{* *}$
}

\begin{abstract}
In the context of an institutionalized multi-nationalist ideology, the language policy in Russia is based on the distinction of the native language of the Russian people and the languages of all other nonRussians. Such a distinction is reflected in the Constitution of the Russian Federation,' federal and regional laws and policy practices that have given advantage to Russian over the other titular languages of the indigenous people in the Russian Federation. This article charts the grand 'shift' in Russian state policy toward ethnic diversity. The Sovietera multinational Leninist/Stalinist approach summarized in the slogan "druzhba narodov" (friendship of peoples) shifted toward a more assimilationist nation-building model. Such ideology reduces the ethnic diversity into just a cultural, folkloric feature of an otherwise monolingual, mono-cultural nation-state. What is the purpose of this discriminatory ethnic and language policy? Our case study of Circassians, one of the ethnic groups in the North Caucasus, demonstrates that, after many decades, such a policy has only caused political and cultural damages to all sides and alienation between them. On the one hand, the assimilationist language policy continues to cause problems with the non-Russian ethnic groups adding to the major challenges that the Russian state faces today. On the other hand, non-Russian ethnic groups, though not yet assimilated into the Russian culture, have undergone significant decrease in terms of their rights to develop their languages.
\end{abstract}

Keywords: Language policy, Russia, Russian, Circassian, North Caucasus, Russification.

"Sufian Zhemukhov, Senior Research Associate, George Washington University, Washington DC. zhemukho@gwu.edu

** Şener Aktürk, Assistant Professor, Koç University, Istanbul. sakturk@ku.edu.tr 


\section{Sufian Zhemukhov - Şener Aktürk}

\section{Rusya'da Tek Dilli Ulusa Yönelim: Kuzey Kafkasya'daki Çerkes Cumhuriyetlerinde Dil Politikası}

Özet

Rusya'nın kurumsallaşmış çok-ulusluluk ideolojisi çerçevesinde, ülkedeki dil politikaları Rusların anadili Rusça ile Rusya'nın Rus olmayan yerli etnik gruplarının anadilleri arasındaki ayrıma dayanmaktadır. Bu ayrım, Rusya Federasyonu anayasası ve çeşitli federal ve bölgesel yasalara da yansımakta, aynı zamanda pratikte de Rusça diğer otokton anadillere göre ayrıcalıklı bir uygulamaya tabi tutulmaktadır. Bu makale, etnik çeşitlilik kavramına yönelik Rusya devlet politikalarının geçirdiği çarpıcı dönüşümü irdelemektedir. Sovyet döneminin 'Halkların Kardeşliği' sloganında sembolleşen Leninist - Stalinist yaklaşım, asimilasyoncu ulus inşası siyasetine yönelmiştir. Bu yeni yaklaşım, etnik çeşitliliği temelde tek dilli ve tek kültürlü bir ulus devletin folklorik bir öğesi haline indirgemektedir. Peki bu ayrımcı etnik ve dilsel politikaların uygulanma amacı nedir? Bu makalede irdelenen Kuzey Kafkasyalı bir etnik grup olan 'Çerkesler' vaka çalışmasının ortaya koyduğu bulgulara göre on yıllardır uygulanan bu politikalar, siyasi ve kültürel anlamda her iki tarafın da zararına olmuş, ve Rus ve Rus olmayan halkların birbirlerine yabancılaşmasına neden olmuştur. Bir taraftan, uygulanmakta olan asimilasyoncu dil politikaları Rusya devletinin Rus olmayan etnik azınlık gruplarla yaşadığı sorunlara ek problemler yaratmakta, öte yandan Rus olmayan etnik gruplar, henüz Rus kültürüne asimile olmadılarsa da, ulusal dillerini geliştirecek yasal hakları açısından ciddi kayıplara uğramışlardır. 


\section{Introduction}

In 1945, Joseph Stalin openly announced for the first time the idea of superiority of the Russian people over others in his famous speech in which he stated, "I would like to raise a toast to the health of our Soviet people and, before all, the Russian [Russkii] people" (Nevezhin 2010, 92-99). Seven decades on, similar speeches are echoing in Kremlin. Russian president, Vladimir Putin, emphasized the role of the Russian language in Russia, "This country is home to 193 ethnic groups speaking almost 300 languages and dialects. I would like to note here that alphabets for many of these languages were only developed in Soviet times through the efforts of outstanding Russian linguists ... It would be no exaggeration to say that the support and care languages enjoy in this country have never existed anywhere in the world" (Putin 2015).

The pathos in President Putin's speech that implies that nonRussian peoples have been unable to develop their own alphabets and should be grateful for Russians' "support and care" for preserving their languages is a characteristic of the Russian Language Policy of the Russian Federation that promotes Russification. The prevalent explanations for such a view of non-Russians, and particularly the North Caucasus region that we will closely analyze in this paper, can be grouped under broad categories of historical legacies, ethnic identities, and socio-economic problems, including the "backwardness" of the non-Russian regions (Bullough 2010; Starodubrovskaia 2012). Such political speeches, however, usually fail to mention that Cyrillic script was imposed on Muslim ethnic groups during the Soviet rule in the 1930s in order to eradicate the usage of the Arabic and Roman scripts and as a measure against pan-Islamism and pan-Turkism in the Caucasus and Volga regions (Slezkine 1994; Wixman 1980; Zhemukhov 2011, 54-71). And specifically, Putin failed to mention in his speech the fact that during his tenure, the Constitutional Court of Russia officially prohibited the use of nonCyrillic alphabets among the non-Russian peoples in the country (Constitutional Court of Russia 2004). In some ways, the use of nonCyrillic scripts, mainly Arabic and Roman scripts, appears to be more threatening and symbolically loaded for the Russian state than the usa of non-Russian languages per se. The restriction on the usa of 
non-Cyrillic alphabets is part of a broader discriminatory state language policy in post-Soviet Russia.

This article critically analyzes how federal and regional laws and policy practices openly favor the Russian language against nonRussian languages. The first section looks into the transformation of Russian state policy from promotion of nationhood to assimilationist nation-building model. The second section explores the loopholes in the Russian Constitution, federal laws, and policy practices that have given priority to Russian over the other titular languages of the indigenous peoples in the Russian Federation. The third section presents a case study for the development of the federal and regional policies toward one of the non-Russian state languages, the Circassian language.

\section{The Great Transformation In Russian State Policy Toward Ethnic Diversity: From Promotion of Multiethnic Nationhood to An Assimilationist Nation-Building Model}

The transition from the Soviet Union to Russian Federation has been followed by a major transformation in state policy toward ethnic groups. ${ }^{1}$ The radical nature of the change is remarkable and worth emphasizing, because the early Soviet Union was the first modern state that went to greatest of lengths to institutionalize ethnic diversity and to reverse centuries of ethnic discrimination, while post-Soviet Russia, at least since president Putin's second presidential term (starting in 2004), if not earlier, increasingly resembled a classic example of an assimilationist nation-state.

"The Soviet Union was the world's first Affirmative Action Empire," as Terry Martin brilliantly described using a retrospective epithet drawn from late $20^{\text {th }}$ century American history (Martin 2001, 1). The Bolsheviks, who eventually established the Soviet Union, sought to recognize, codify, and institutionalize ethnic and linguistic diversity among their subject populations, under first Lenin and then

${ }^{1}$ Much of this section builds on one of the current authors' book on this subject. See Aktürk, Şener. Regimes of Ethnicity And Nationhood In Germany, Russia, And Turkey. Cambridge University Press, 2012, pp. 197259. 
Stalin. In the all-Soviet census of 1926, almost two hundred ethnic categories were codified and counted (Hirsch 2005, 121). Francine Hirsch convincingly argued that "The classification of all Soviet citizens under the rubric 'nationality' in the First All-Union Census, which was conducted in 1926, constituted a critical step in the process of internal transformation that shaped the Soviet state" (Hirsch 2005, 102). In this process, Soviet Union sought to create a Communist elite from every ethnic group in order to ensure the longterm survival and deepening of the one-party dictatorship and the social transformation of the entire Soviet society.

Emphasizing and privileging ethnicity as an identity category had another, somewhat implicit and thus less noticed, goal that was eventually achieved: displacing the previously hegemonic role of religious identity, and replacing it with a folkloric ethnic identity that was officially described as 'national in form, socialist in content.' This was a momentous achievement, since religious identity was the primary identity in the Tsarist Russian Empire, just as was the case in many of its chief competitors, such as the neighboring Ottoman Empire at the time (Aktürk 2013, 16-23), if not even later (Akturk 2009, 893-909). Therefore, the displacement of potentially and actually dissident religious identities and their replacement with relatively innocuous ethnic/national 'forms,' ideally cleansed of any anti-socialist 'content' that could justify or encourage dissidence against the new regime, was one of the most critical stages in the consolidation of the Soviet Union. Exactly when this was achieved is beyond the purview of this article, but suffice it to say that collectivization campaign that emasculated and devastated the peasantry (Scott 1998) was also an important hurdle in destroying anti-Soviet religiosity, and the Great Terror of the 1930s may also be another important hurdle in the transformation of the individuals' identities.

The officially engineered shift from religious categories to ethnic categories as the primary identification of individuals and communities had the net effect of resulting in fragmentation of the former, and flourishing of the latter, of identity. People who mostly identified simply as Christians during Tsarist times began to emphasize their ethnic Russian, Ukrainian, or Belarusian identities. 
Likewise people who mostly identified simply as Muslims during Tsarist times began to emphasize their ethnic Uzbek, Turkmen, Kyrgyz, or Tajik identities. Whilst this can be macroscopically exemplified as in the ethnic compartmentalization of Orthodox, Catholic or Muslim communities, it also has microscopically exemplified in the further compartmentalization of Western and Eastern Circassian ethnic and linguistic identities and their corresponding territories by the Soviet regime. There were attempts to create a pan-Circasssian or pan-Caucasian identity based on a single language and alphabet, but the Soviet delimitation of the North Caucasus moved in the complete opposite direction, and Soviet authorities deliberately recognized two separate Circassian languages and designed two separate alphabets, as discussed in Section 3 of this article.

Early Soviet policy, however, entailed an undeniable promotion of ethnic and linguistic particularities and a principled stance against assimilation, at least from the time of the Bolshevik Revolution in 1917 to the early 1930s. In this period, dozens of ethnic categories were given their autonomous territories, with each ethnic group's language becoming the official, 'titular' language of its autonomous territory, combined with robust ethnic affirmative action policies to build, nurture and promote a devoutly Communist elite from every ethnic group. No other modern state undertook such extensive ethnic affirmative action policies before the Soviet Union.

The question as to why the Soviet Union undertook such policies is one that has fascinated many scholars working on this subject. Without going into too much detail, one can posit at least two different but potentially overlapping causal arguments explaining the Soviet Union's curious choice of an avowedly multiethnic and seemingly consensual institutional arrangements based on ethnic quotas for political and other leadership cadres. The first argument is based on internal power politics: Bolshevik leaders, in particular Lenin and Stalin, observed with alarm the collapse of the AustroHungarian Empire, despite the efforts of Austro-Hungarian socialists, and they devised their 'nationalities policy' in response to the fear of such a dissolution, hence conceding significant ethnic, cultural, and territorial autonomy to different groups that would constitute the 
Soviet Union (Martin 2001, 5-6). The second argument is based on ideology: Lenin and Stalin were convinced that the ideals of the socialist revolution and reconstruction in the formerly Russian Soviet lands could only succeed in earnest if it was genuinely embraced by all ethnic groups, which justified significant ethnic, cultural, and territorial autonomy for different groups. Combining ideology and power politics on a global scale, a third line of argument would emphasize that the Soviet nationalities policy had a significant value in propagating the socialist ideology among African and Asian peoples living under European colonial rule in the early $20^{\text {th }}$ century.

All three arguments are plausible, and they may all be correct to different degrees, but it is beyond the scope of this article to adjudicate between them. However, it is important to note that regardless of which explanation is correct, promotion and institutionalization of ethnic diversity is seen as a means to a higher end (i.e. the building of socialism), and as such can be seen as a 'transitional measure,' however elusive the goal of realizing a classless, conflict-free socialist utopia may seem. Soviet nationalities policy also had an evolutionary character, whereby the 'flourishing' (rastsvet) of ethnicities was to be followed by their 'coming together' (sblizhenie) and eventual "merger" (sliianie) once socialism was fully accomplished (Hirsch 2005, 197-227).

\section{1 "The Great Retreat" From Affirmative Action and the Elevation of the Russian Language to Dominance In the Soviet Union, 1933- 1953}

Nicholas Timasheff famously argued that around 1934, the Soviet political leadership led by Stalin concluded that Communism had not sufficiently taken root among the population, and hence they "retreated" from some of the most revolutionary aspects of state policies and instead resurrected some of the some traditional attitudes reminiscent of pre-revolutionary Russia in order to rally popular support for the new regime (Timasheff 1946). This is in some ways similar to Leon Trotsky's also very famous argument that Stalin 'betrayed' the original ideas that inspired the Bolshevik Revolution (Trotsky 1937). More importantly, these arguments about a palpable shift in the Soviet regime's methods if not also in its ultimate goals 
are paralleled by certain changes observed in cultural and ethnic policies, which are the chief concern of the current article. For example, there was a revival of pre-revolutionary, non-socialist, ethnic Russian heroes including some Tsars and even religiously inspired warriors (Platt 2006).

Most importantly for our current purposes in this article, the same critical turning point also corresponds to a major 'retreat' in ethnicnational affirmative action policies in the Soviet Union. Terry Martin describes this new period as "the revised Soviet nationalities policy (1933-1939)," and dates its beginning to the "Skrypnyk affair" that began in December 1932, whereby Mykola Syrypnyk, who "was the Soviet Union's paradigmatic national communist" with impeccable Bolshevik credentials including party membership since 1899, was 'accused of defection to nationalism' (Martin 2001, 344-345). As a result, inter alia, "although the commitment to linguistic korenizatsiia was never formally abandoned, it became an increasingly low priority and the Russian language assumed a dominant position in all the non-Russian republics except Georgia and Armenia" (Martin 2001, 393). Thus, the Russian language was already established as the primus inter pares in almost all the Soviet republics by the end of the 1930s. This is a significant observation for the main argument in this article. In short, although the Soviet Union was originally the most ardent supporter of multiethnic, multiculturalist, affirmative action policies when it was founded in the 1920s, the political leadership in Moscow gradually shifted toward assimilationist state policies already during the Soviet period but decisively after the collapse of the Soviet Union.

The late 1930s and the 1940s witnessed much more gruesome policies against non-Russian ethnic groups, most infamously the mass deportations of many ethnic groups including Volga Germans, Crimean Tatars, Chechens, and Meshketian Turks, for alleged collaboration with Nazi Germany. Ethnic groups that were deported in their entirety due to this allegation became known as the "Punished Peoples" in Soviet studies and up to half the population of some ethnic groups died as a result (Nekrich 1981). These examples show that the Soviet sponsorship of ethno-linguistic revival and various substantive policies of positive discrimination in the $1920 \mathrm{~s}$ 
gave way to massive discrimination against and outright persecution of some ethnic groups by the 1940s. This is a significant turning point that needs to be noted in evaluating Soviet state policies on ethnolinguistic diversity in the $20^{\text {th }}$ century.

\title{
1.2 Khrushchev's Construction of the Soviet Nation and Linguistic Russification: 'A New Historical Community of People' and the Education Laws of 1958-59
}

There was yet another major shift in emphasis that one observes with the coming to power of Nikita Khrushchev as the new Secretary General of the Communist Party of the Soviet Union (CPSU), which was manifest in at least six major policies:

\begin{abstract}
"[Khrushchev's] policies that were most symptomatic of the tendency toward creating a homogenous Soviet nation included 1) the 'Theses of November 1958,' which overhauled the Soviet education system and substantially increased the pressure for linguistic assimilation through the adoption of the Russian language; 2) the revitalization of the militant atheist propaganda... [seeking to make] atheism as the common belief system of the entire citizenry, hence homogenizing society; 3 ) the idea of 'cadre rotation,' which... would aid the formation of a non-ethnic, all-Soviet, bureaucratic class... 4) the 'Virgin Lands' project, which involved the moving of Slavic and other European settlers to Kazakhstan... 5) most importantly, the propagation of the idea of a 'Soviet Nation' as a 'new, historical community of people,' in conjunction with a declining emphasis on 'brotherhood of nations'; and 6) the attempt to remove ethnicity from the internal passport..." (Aktürk 2012, 202)
\end{abstract}

In terms of Khrushchev's reshuffling of policies and institutions, the Soviet education laws of 1958-59 deserve particular attention for their critical role in increasing the pressure for linguistic Russification (Bilinsky 1962, 138-157). What made this reform unusually controversial, and led to significant resistance especially in Azerbaijan and Latvia was changing the "position of Russian vis-à-vis the titular languages in the general elementary and secondary schools of the non-Russian Union Republics" (Bilinsky 1962, 138). With these reforms, school children attending Russian schools in the non-Russian 
ethnic republics were given the 'option' not to study the titular language of the republic within which they were living. In other words, an ethnic Russian or even an ethnic Uzbek attending a Russian-language school in Uzbek Soviet Socialist Republic could now complete his entire education in Russian, without any familiarity with the Uzbek language, not even as a limited secondary language. Given that Russian-language schools were on average better equipped than non-Russian schools, and since Russian language offered better opportunities for upward mobility, this meant many more families would 'choose' to educate their children only in Russian. This was the second critical turning point toward linguistic Russification in the Soviet Union.

Khrushchev's other major innovation in pursuit of assimilationist nation-building was his construction and propagation of the idea of a 'Soviet nation,'(Sovetskii narod). This term has often been translated as 'Soviet people,' rather than 'Soviet nation.' However, as one of the coauthors of the current article argued at length elsewhere (Aktürk 2012), there are many reasons as to why 'Soviet nation' would be a more accurate translation of Sovetskii narod in studies of ethnicity and nationalism. Most importantly, many other entities that are most often discussed as 'nations' in English are regularly discussed as narods in Soviet publications, such as the Japanese narod and the Italian narod. Soviet publications use the term, natsional'nost, which is often translated inaccurately as 'nationality,' only when discussing ethnic diversity within a country, as in ethnic processes in Bulgaria or France. Therefore, it is more accurate from an analytical point of view to translate narod as nation, and national'nost as ethnicity in this context. In this sense, Soviet official discourse clearly described Soviet nation (narod) as being made up of diverse ethnic groups, which is not at all uncommon if one considers many other such examples (e.g., American narod/nation). Language was related to these discussions around Soviet nationhood because the promotion of Russian as the language of interethnic communication for the entire Soviet Union went hand in hand with the promotion of the new idea of Soviet nationhood.

Khrushchev most clearly defined the concept of the Soviet nation at the $22^{\text {nd }}$ Party Congress of the CPSU in October 1961. Among many 
other common characteristics such as a common goal, worldview, economic base, social-class structure, and even spiritual character (dukhovnyi oblik), this new Soviet nation also implicitly had a common language, Russian, which was always described as the language of interethnic communication throughout the Soviet Union (Aktürk 2012, 205). The Propagation of the discourse of Soviet nation escalated throughout the 1960s and the 1970s. However, both Khrushchev's and Brezhnev's attempts to remove ethnicity from the internal passport failed (Aktürk 2012, 211-213). These failed attempts to remove ethnicity from the internal passport under Khrushchev and Brezhnev were also aimed at creating a supra-ethnic or post-ethnic Soviet nationhood. Removal of ethnicity from the internal passports would be carried out successfully only after the collapse of the Soviet Union, under president Yeltsin, as the next section will elaborate.

\subsection{Collapse of the Soviet Union and the Turn Toward Assimilationist Nation-Building In Russia: Removal of Ethnicity From Internal Passports Under Yeltsin}

The collapse of the Soviet Union radically changed the calculus of power in Moscow between proponents of a more assimilationist nation-building model and those in favor of preserving the multinational Soviet era status quo. The first (and perhaps the only) democratically elected president of the new Russian Federation, Boris Yeltsin, spent the first five years of his presidency (1991-1996) struggling against his Communist opponents, first in the Congress of People's Deputies (1991-1993) and later in the new Russian parliament, Duma, and finally in the presidential election of 1996. While struggling against his opponents in Moscow, Yeltsin was also engaged in redefining the central government's relationship with ethnic republics, mostly through bilateral treaties as in the case of Tatarstan. He also launched the infamous and devastating war in Chechnya as part of the same process of striking a new balance between the center and the regions. These power struggles at multiple levels limited central government's capacity for interference in the ethnic autonomous republics until Yeltsin's reelection to his second presidential term in 1996. However, this can also be described as a preparatory period. Yeltsin's first Minister of Nationalities, the famous 
ethnologist Valerii Tishkov, became a well-known proponent of a new, supra-ethnic and territorial idea of 'Rossian' nationhood, in which ethnic identities would be deemphasized (Akturk 2010, 314-341).

'Rossian' (россияне) is a term that Tishkov, who was and still is a key figure of ethnic policy making in Russia, promoted in English, based on the distinction between Russkii (русский) and Rossiiskii (российский) in Russian language. The first term, Russkii, refers to ethnic Russian, who make up approximately four-fifths of the population of the Russian Federation. The latter term, Rossiiskii, indicates a relationship with Russia as a state and country, and thus refers to all inhabitants or at least all citizens of Russia regardless of their ethnic background. However, this very critical distinction is lost in English, where both Russkii and Rossiiskii are translated simply as 'Russian.' Therefore, Tishkov in particular advocated promoting the use of "Rossian" as a new word in English, in order to distinguish it from "Russian," which would then refer exclusively to ethnic Russians. ${ }^{2}$ Even though Tishkov's attempt to popularize this alternative term in the English language mostly failed, it is important to note that his efforts to promote a new, supra-ethnic Russian national identity and a new form of nationalism were the intellectual handmaidens of the reform that removed ethnicity from the Russian internal passports.

Although majority of the Russian citizenry did not favor the removal of ethnicity from the internal passport (Akturk 2010, 325), Yeltsin signed an executive decree in 1997 removing it, hence opening the gates to more massive assimilation in future generations. Passport reform was met with recalcitrant protests in a number of ethnic republics, most notably in Tatarstan, but also in Bashkortostan, Ingushetia, and Kabardino-Balkaria, among others (Akturk 2010, 333-334). It is important to note that the Yeltsin administration adamantly refused to allow even the option of voluntarily stating one's ethnicity, which is what a number of ethnic republics, including Tatarstan, sought to do. This insistence on erasing individual ethnic records, as well as a similar reform that removed ethnic identity from birth certificates, demonstrates that

\footnotetext{
${ }^{2}$ See the relevant discussion in Tishkov 1997, 246-271.
} 
the elimination of ethnic categories in personal documents was a consistent state policy under Yeltsin.

\subsection{Continuing Along the Assimilationist Course: Dissolution of Ethnic Autonomous Okrugs and the Demotion of the Ministry of Nationalities Under Putin}

The fourth and final turning point in the grand shift away from multiethnic nationhood and toward assimilationist nation-building in Soviet and Post-Soviet Russian policies took place during Vladimir Putin's rule. Putin, who served two consecutive terms as President (2000-2008), followed by one term as Prime Minister (2008-2012), was elected to a third, non-consecutive presidential term in 2012. Already in his first two terms in presidency, Putin administration undertook two reforms that directly and symbolically demonstrated its assimilationist nation-building strategy in deemphasizing the ethnic diversity of Russia. First, the Ministry of Nationalities was dissolved or rather demoted to the level of an under-secretary with a significantly different name, namely Department of Interethnic Relations, which was placed under the Ministry of Regional Development (Aktürk 2012, 253). Second, four ethnic autonomous okrugs, namely the Komi Permiak (in 2005), the Taymyr (DolganoNenetskii) and the Evenk (both in 2007), and the Ust-Orda Buryat (in 2008) ethnic autonomous okrugs, were dissolved and merged with the larger ethnic Russian oblasts surrounding them (Aktürk 2012, 254). As such, four ethnic subjects of the Russian Federation were eliminated within four years. Whilst these two policy changes directly undermine the legal and institutional expression of ethnic diversity in Russia, there are numerous other changes in the federal structure of the country that Putin administrations have undertaken over the years that also indirectly weaken the power and resources of the ethnic autonomous federal units. A detailed discussion of one particular new piece of legislation regarding the regulation of linguistic diversity, namely, the Law on the State Language of the Russian Federation (2005), is provided in the following section, followed by a third section focusing on the impact of these constitutional, legal, and institutional changes in favor of 
Russification on the case of state policies toward the Circassian language.

In partial conclusion, although the Soviet Union under Lenin and Stalin was founded on the basis of institutionalizing multiethnic diversity at every level in a way that was unprecedented and 'progressive' for its time in the early 1920s, this institutional heritage and policies have passed through at least four critical turning points as analyzed above, starting with Stalin's revisions in 1934, gathering pace with Khrushchev's education reforms in 1959, and decisively turning toward assimilation with Yeltsin's passport reform in 1997 and Putin's various policies that followed up on the assimilationist course charted by Yeltsin.

\section{Russian Federal Policy Towards Non-Russian Languages}

The national ideology in Russia is known as institutionalized multinationalism (Brubaker 1994, 47-48). In this context, the language policy in Russia is based on the distinction between the native language of the Russian people and the languages of all other, nonRussian, peoples. Such a distinction is reflected in The Constitution of the Russian Federation. And when, in 2001, the Russian Federation signed the European Charter for Regional or Minority Languages, it was perceived by many in Russia as if the ratification could undermine the unity of Russia by diminishing the Russian language" (Fedorova 2015).

Some scholars argue that the Russian language policy is similar to those in many democratic states in that "the legal recognition of one language as the only state language, which is meant to prove the national unity, is typical of states encouraging ethnic and cultural homogeneity" (Belov 2015, 126). Such a position, however, does not take into consideration that democratic countries do not have policies of dominance of one language over others - that is, policies that are similar to the policy of Russification in Russia. The Constitution of the Russian Federation states the equality of all languages in Russia and forbids language discrimination. The specific articles of the Constitution, however, declare the superior role of the native language of the Russian people over the languages of the other native peoples in the country. The Constitution also contains 
other loopholes that the state authorities can use for language discrimination. In analyzing those articles and clauses, we will focus mostly on the disadvantages they provide for non-Russian native languages, rather than on why and how the Constitution and the authorities emphasize the role of the Russian language.

One of the Constitution's specific articles on the language, Article 26, states, "Everyone shall have the right, with a free choice, to use his or her native language as the language of communication, upbringing, education and creative work" (The Constitution of the Russian Federation 1993). The terms "right to use his or her native language" and "choice of language" in this article create loopholes that lead to the language discrimination in practice. What does it mean to have the right to choose a language? In another article, the Constitution clarifies that it does not mean the right to choose between Russian and another language; the citizens do not have right to choose other languages over Russian. Article 68 establishes Russian as the only mandatory language in the country, and specifies that Russian is not a language of choice. The first paragraph of Article 68 states, "The Russian language shall be a state language on the whole territory of the Russian Federation." Thus, Articles 26 and 68 establish that all citizens of the Russian Federation, including ethnic Russians and non-Russians, have to learn the Russian language. The free choice of language, in this context, means that the citizens of the Russian Federation are free to choose or not to choose a second language besides Russian. In practice it means that ethnic Russians must use their native language, while other nationalities have the right to use - or not to use - their native languages. This exceptional status of the native language of ethnic Russian majority over ethnic minorities in such a multiethnic state as the Russian Federation opens the way to ethnic discrimination.

What about other native languages in Russia? Do ethnic Russians have to learn any of them? Are other languages mandatory for their native speakers? The same article partly explains the extent of the rights other languages have. The second paragraph of Article 68 gives right to the regions (republics) to establish a second state language, alongside Russian, on their territories, "The republics shall have the right to establish their own state languages. In the bodies of state 
authority and local self-government, and state institutions of the republics they shall be used together with the state language of the Russian Federation." Strictly speaking, we see here not the right to choose a language. Instead, we see that the state imposes the Russian language as mandatory over Russians and other nationalities in the country, while other nationalities have the right to establish or not - their languages on their territories. The Constitution, however, does not make it mandatory for Russians and other peoples to learn a second language. Whilst the Constitution establishes the native language of Russian people as the mandatory for Russians and non-Russians, it does not establish any other mandatory language in any part of Russia. Ethnic Russians do not have to learn a second state language if they live in a Republic that have established its own second state language. Therefore, the term "choice" in the Constitution may be interpreted only in one way - a right to choose or not choose a second language with Russian. This is the most important loophole that is used for the policy of Russification and language discrimination in Russia.

Can the term "choice" in this context be interpreted another way, as a right to choose between languages? It is certainly not a choice between Russian and any other language. The third paragraph of Article 68 exhibits the same ambiguous approach, "The Russian Federation shall guarantee to all of its peoples the right to preserve their native language and to create conditions for its study and development." This is a contradictory statement that has two parts. The first half of this sentence emphasizes guaranties of the 'right to preserve,' but not the direct preservation of the languages. It means that the state withdraws from the business of supporting languages, and only promises that it will not prohibit preservation of nonRussian languages. Literaly, the Constitution announces that the state does not guarantee preservation of the non-Russian languages, but merely guaranties that people have the right to preserve - or not their native languages. The second part of the sentence clarifies again that the state does not create conditions for the study and development of non-Russian languages, but only guaranties that people have right to create conditions for the study and development of their languages on their own, without any help from the state. 
Article 68 establishes three different types of languages on the territory of the Russian Federation. The language of the Russian people is most privileged; it is supported at federal level, and neither ethnic Russians nor non-Russians can avoid learning it. The republics have the right to establish - or not establish- their own native languages on their territories and support - or not support- them at regional level. All other native languages without regional state status do not receive any support from the state, and it is up to the people if they want to preserve them. Though the wording of the Article 68 sounds as if it "guarantees" something, however, in terms of practical policy, it establishes a discrimination toward non-Russian languages.

We can see the discriminatory character of this language division in the case of the Circassian language. First, in the three republics where Circassian language is established as a state language Adygea, Kabardino-Balkaria, and Karachay-Cherkessia - the role of the Circassian language is undermined and the role of Russian language is over-emphasized. Second, three other regions with indigenous Circassian population - North Ossetia, Stavropol krai, and Krasnodar krai- did not establish Circassian language as a state language, and Circassians in those regions do not have even the limited language rights assigned to them by the Constitution. Third, the exceptional status of the Russian language, prevents Circassians in diaspora from resettling back in the land of their ancestors, partly because they do not speak Russian, and partly by other specific laws and administrative practices directly interfering with Circassian repatriation. The majority of Circassians were expelled from the Caucasus after the Russian conquest in the middle of the $19^{\text {th }}$ century. Today, several millions Circassians live in about fifty countries over the world.

Apart from the constitutional definition, there is a fourth category of 48 nationalities officially recognized as small indigenous peoples of Russia. Section 3 of this paper provides a case study on Circassian language, and at this point it is worth mentioning that the list of minor indigenous peoples of the Russian Federation includes the Shapsugs, a Circassian sub-ethnic group, and the Abazins, who speak a related language (Federalnyi Zakon 1999). Also the parliament of 
Kabardino-Balkaria appealed to the Russian government to give the status of small indigenous people to Ubykhs, another member of Abkhaz-Adyghe ethno-linguistic family that was entirely deported from the Caucasus into the Ottoman Empire in 1864 (Postanovlenie 2014).

The Constitutional articles are detailed in federal laws that regulate the language policy in the Russian Federation. The federal level policy is based on the Constitution of the Russian Federation (1993), the Law on Languages of the Peoples of the Russian Federation (1991, amended in 1998) and the Law on the State Language of the Russian Federation (2005). The regions have their own laws, which we shell analyze in the third section. The policy of discrimination against non-Russian languages uses three strategies. First, the language discrimination policy builds on the loopholes in the Constitution, interpreting some of the Constitutional articles in favor of the Russian language. Second, the Federal and regional parliaments change and add to the acts that regulate the language policy and in many cases change them in favor of the Russian language. Third, the federal and regional parliaments issue new laws that give preferences to the Russian language and disadvantage the minority languages in Russia. The language policy in Russia changes gradually toward giving preferences to the Russian language and creating more disadvantages for the minority languages. This process is not always a straightforward one, and it involves cooperation of many actors and is based on negotiations between federal and regional elites, politicians and civil society.

The Russian Federation not only inherited some features of the Soviet language policy of Russification but also developed them in new directions. The new Constitution of Russian Federation in 1993 established the concept of the superiority of the native language of the Russian people over all other native languages in the country. During the fallowing decades, the federal and regional legislations developed numerous amendments in specific laws on language that emphasized the role of the Russian Language and undermined the role of other native languages. The idea of superiority of the Russian language also became part of Kremlin's foreign policy. Putin's regime has developed the ideology of Russkii Mir (Russian World) based on 
the idea of the exceptional role of the Russian language not only in Russia but also in those regions of foreign counties where part of the population speaks Russian. The idea of protecting Russian-speakers became one of the pretexts of the annexation of Crimea by Russian in 2014 and initiated diplomatic conflicts with Ukraine and Baltic states (Laruelle 2015; Morozov 2015). The language policy also defined the status of the compatriots living abroad - the latest amendments in the law, in 2010, stated that, in order to return to their "homeland," foreign compatriots must learn Russian regardless of whether they are Russians or non-Russian indigenous peoples of the Russian Federation (Federalnyi Zakon 2015).

Though the Constitution states equality of all languages and forbids discrimination of languages, the Constitution's clauses that are detailed in the special Law on Languages of the Peoples of the Russian Federation (1991 amended in 1998), and in the Law on the State Language of the Russian Federation (2005) emphasize the special role of the Russian language as the means of national communication and protect and regulate changing its literary norms.

\section{Case Study: State Policies Toward the Circassian Language}

Circassians are an indigenous people of the North Caucasus. All Circassians call themselves Adyghe and their language Adyghebze. Circassians live in six regions of Russia - the republics of Adygea, Kabardino-Balkaria, Karachay-Cherkessia, and North Ossetia as well as the Russian dominated Stavropol Krai and Krasnodar Krai of the North Caucasus. Though all Circassians identify themselves as one people, Russian official terminology has designated for them different terms, mostly depending on territorial definition (Tsutsiev 2013). On the one hand, such a complicated terminology makes it harder to understand general tendencies and language policy. On the other hand, those divisions reflect the official Russian ethnic and language policy toward Circassians. In this article, we will use two simple terms - 'Eastern' and 'Western' - to indicate the main dividing and unifying tendencies in the language policy in the Circassian regions of Russia.

Though the Russian encounter with Circassians was romanticized in the literary masterpieces of Alexander Pushkin, Mikhail Lermontov, 
and Leo Tolstoy, the reality weas dramatically less romantic (King 2010; Grant 2009; Layton 2005). After the final Russian conquest of Eastern Circassia in 1822 and Western Circassia (including Ubykhia) in 1864, the Circassian lands and population gradually became divided between different regions of Russia (Richmond 2013). According to the contemporary division, Circassians are divided between six Russian regions; depending on the region, Circassian language has different status. Western Circassian has been recognized as a state language in the republic of Adygea (1995), whilst Eastern Circassian has been recognized as a state language in Karachay-Cherkesia (1996), and Kabardino-Balkaria (1997). Recognition of Circassian as a state language was based on Article 68 of the Constitution of the Russian Federation that stated, "The republics shall have the right to establish their own state languages." Circassians communities with their language recognized as a state language are called titular nationalities - that is, a nationality whose name is mentioned in the title of a region. According to the Russian terminology, Circassian titular nationalities include Adygeans in Adygea, Kabardians in Kabardino-Balkaria, and Cherkess in Karachay-Cherkesia. Other regions with Circassian populations as indigenous people include Krasnodar Krai for Western Circassian, and Stavropol Krai and North Ossetia for Eastern Circassian. In those regions, however, Circassians are not recognized as the titular nationality. Circassian is not recognized as a state language in those regions.

Circassian language became divided into two literary dialects during the campaign for eradication of illiteracy in Soviet Russia in the 1920s and 1930s. The 1919 decree 'On Elimination of Illiteracy' introduced education of all citizens aged 8 to 50 to teach them how to read and write in their native language and, voluntarily, in Russian (Postanovlenie 1920). Local Circassian linguists, Tuta Borukai, Khasan Elberd, Mukhamed Tsago, and Magomed Dyshek, became inspired by the Bolshevik goal of achieving universal literacy for all Soviet citizens in their native languages. The early Soviet state, however, lacked comprehensive language policy, and it caused the Circassian alphabet to go through three stages of development, adopting Arabic, Roman, and Cyrillic scripts one after the other. These abrupt linguistic experiments happened within first two decades after the Bolshevik 
revolution. As one Circassian novelist, Asker Eutykh, put it, "Three times, people went to sleep literate at night, and woke up illiterate in the morning" (Baku 2014, 69-80). As a result, linguists created Western and Eastern Circassian alphabets, or, according to the Russian terminology, the Adygean and Kabardian-Cherkess alphabets (Kumakhov 1989; Kumakhova 1972).

First, local linguists designed a unified Circassian alphabet based on Arabic script because they understood their task too literarily and tried to use the existing education system represented by Islamic elementary schools. However, they failed to take into the consideration the anti-religion state policy, according to which the use of Islamic education was inappropriate in the Soviet state. As soon as anti-Islamic Soviet policy was understood, the script was changed to Roman. Anatoly Lunacharsky, the Soviet minister of education that promoted the change from Arabic to Roman script noted that his reform met considerable resistance on religious ground among the non-Russian people (Lunacharsky 1930, 20-26). During the change of the Circassian alphabet to the Roman script, two separate alphabets were designed, one for Eastern and the other one for Western Circassian. After the Circassian language was separated by two different alphabets, the Kremlin blocked all local efforts for unification of the Circassian alphabet. However, the Soviet authorities also feared that Roman script would engender pan-Turkist ideas among the Muslim Circassian population and ordered that the alphabet be changed to a Cyrillic script. Russian linguists were sent to the Caucasus to supervise the alphabetic reform. The Kremlin ordered that two new separate, Eastern and Western, Circassian alphabets be designed on the basis of the Cyrillic script, which Circassians have have been using ever since (see Table 1).

Table 1. Development of Circassian alphabets

\begin{tabular}{|l|l|l|}
\hline Scripts & Eastern & Western \\
\hline Arabic & $1920-23$ & $1918-27$ \\
\hline Roman & $1923-36$ & $1927-37$ \\
\hline Cyrillic & $\begin{array}{c}\text { Since 1936 (with } \\
\text { changes in 1939) }\end{array}$ & Since 1937 \\
\hline
\end{tabular}


Eastern and Western Circassians have different alphabets, in spite of the fact that both are based on Cyrillic script and both dialects have similar phonetic structure. The differences in alphabets help drive Eastern and Western Circassian apart, something that Circassian scholars and activists regard as one of the main challenges for the Circassian language. The territorial division between Kabardino-Balkaria and Karachay-Cherkessia also helps to form new differences within Eastern Circassian, further influenced by local dialectal peculiarities, mostly in the lexical sphere. Recently, a group of prominent Circassian scholars from the three Circassian republics designed a unified alphabet for the Western and Eastern Circassian. The unified Circassian alphabet was discussed and approved on three special conferences that involved practically every Circassian linguist in Russia. After the discussion, the scholars submitted, in 2000, the project to the local parliaments of Adygea, Kabardino-Balkaria, and Karachay-Cherkessia (Kumakhov 2006, 695-698). The project, however, never became a law.

In spite of the existing alphabets and educational infrastructure, the level of education in the native language is rather low, and a part of the Circassian community does not speak their native language at all. The decrease of non-Russian languages in Soviet time was disguised by the façade of equality between titular nationalities in each region. Kabardino-Balkaria presented one of the most characteristic cases. A prominent Circassian politician, Timbora Malbakhov, who led the Kabardino-Balkarian Republic for three decades, established the unwritten rules of a sort of 'Lebanese protocol' of appointment by ethnic quota. In any administrative office, institution, or factory the top appointment went to a Circassian (Kabardian), the second to an ethnic Russian, and the third to a Balkar (Urban, Igrunov and Mitrokhin 1997; Malbakhov 2008). After the fall of the Soviet Union, Balkars were nominally promoted to the second place while Russians became third. More importantly, the fall of Soviet Union gave the rise to mass popular actions that many local intellectuals embraced as a 'national revival' for the North Caucasus with leadership dominated by intelligentsia who favored symbolic means towards achieving their goals of democratization (Derluguian 2005; Dunlop 1998; Lieven 1998). Support for the local 
languages became one of the goals for the mass movements of the time, though the activists generally lacked any comprehensive political program, and were more of 'language dreamers,' rather then realistic political reformers (Gould 2010, 143-166).

Neither the facade of equality nor "national revival" during the Soviet rule slowed down Russification or improved the knowledge of the Circassian language of its native speakers. In fact, the changes occurred after the collapse of the Soviet Union and the processes that some observers labeled as de-modernization (Bourdieu 1973, 83-89; Derluguian 2005), impacted Western and Eastern Circassians equally. Table 2 shows the dynamics for Circassian speakers based on selfestimation of language fluency. The number of Eastern Circassians that did not speak their native language increased almost twice since 1989 through 2010 - from 38,100 to 74,338 among Eastern Circassians, while the number of Western Circassians that did not speak their native language remained almost the same (McConnell, Solntsev and Mikhalchenko 2000, 52, 164; Vserossiiskaia Perepis 2010, 9-21, 142143). Such a rapid increase in the number of Eastern Circassians, who do not speak their native language, from 8.7 to 12.6 percent, indicated a higher level of Russification because those Circassians who did not speak their native language usually spoke only Russian.

Table 2. The number of Circassians and speakers of the Circassian language in Soviet and post-Soviet times (2010 and 1989 censuses)

\begin{tabular}{|l|l|l|l|l|l|l|l|l|}
\hline & \multicolumn{3}{|c|}{2010} & \multicolumn{5}{c|}{1989} \\
\hline & Eastern & \multicolumn{2}{|c|}{ Western } & \multicolumn{2}{l|}{ Eastern } & \multicolumn{2}{l|}{ Western } \\
\hline $\begin{array}{l}\text { Total } \\
\text { Circassian } \\
\text { population }\end{array}$ & 590,010 & $\%$ & 124,835 & $\%$ & 437,000 & $\%$ & 122,908 & $\%$ \\
\hline $\begin{array}{l}\text { Speak } \\
\text { native } \\
\text { language }\end{array}$ & 515,672 & 87.4 & 119,463 & 95.7 & 398,900 & 91.3 & 117,067 & 95.2 \\
\hline $\begin{array}{l}\text { Do not } \\
\text { speak } \\
\text { native } \\
\text { language }\end{array}$ & 74,338 & 12.6 & 5,372 & 4.3 & 38,100 & 8.7 & 5,841 & 4.7 \\
\hline
\end{tabular}

Sources: McConnell, Solntsev and Mikhalchenko 2000: 52, 164; Vserossiiskaia Perepis 2010: 9-21, 142-143. 
Circassian linguists criticize local governments for the 'absence of comprehensive language policy' (Timizhev 2014, 130). It is a separate counter-factual question to ask why local non-Russian elites are not able to oppose Russification imposed by the federal power, since it is a broader issue similar to the question why no opposition of any ideological kind could be consolidated in Russia proper, although scholars like Henry Hale and Stephen Hanson suggest important clues (Hale 2005; Hanson 2010). It is enough for the purpose of our research to state that the weak language policy created a significant imbalance in the knowledge of Russian and non-Russian languages. The results of academic studies show that, whilst the knowledge of Russian is low in non-Russian rural areas, Circassian, on the contrary, is less used in cities. This kind of government-sponsored study conducted by state universities reflects the state policy approach that favors Russian against non-Russian language in the way that their recommendations usually show more concern with the level of knowledge of Russian rather than non-Russian languages. Two recent studies are characteristic of the trend that, whilst indications of the problems of the Russian language cause alarm on federal level, problems of the Circassian language are never mentioned at the federal level and perceived as less alarming even at the regional level. On the one hand, a recent study on the usage of the Russian language in different Russian regions conducted by Moscow State University showed that "in Kabardino-Balkaria, there was impossible to conduct the research in several villages because of the complete absence of the knowledge of the Russian language" (Balabas 2015). The low knowledge of Russian language created alarm at the federal level, when, after the research, the president of Moscow State University, Viktor Sadovnichy, made a statement at the meeting of the Russian government's Council for the Russian Language, "We need to intensify the work on the Russian language in the Caucasus region. We are loosing the Caucasus in terms of the Russian language" (Balabas 2015). Other high ranking Russian bureaucrats expressed their concern, including the Minister of Culture, Vladimir Medynsky who came up with an idea to develop teaching Russian at school at the expense of other languages. 
Federal policy of promoting the Russian language at the expense of other native languages in Russia does not have unanimous support of the academic community. Sergei Arutyunov, a respected Russian academic, has stated, "UNESCO has declared all North Caucasus languages as moribund. In particular, the prognosis for the existence of the Circassian language is 25 to 50 years. And here, a year after the acknowledgment of such a horrible fact about the condition of the Circassian language (and other regional languages in Russian Federation), the Minister of Culture, Vladimir Medynsky, comes up with an initiative to increase the teaching of the Russian language at the expense of the class-hours that are designated to teaching foreign and regional languages, though it would seem that it should be completely the opposite" (Arutyunov 2014, 88-95).

On the other hand, similar studies at the Kabardino-Balkarian State University (KBSU) showed low knowledge of Circassian language among urban Circassians. According to a research, less than 17 percent of Circassians in Nalchik indicated Circassian as the language of parental instruction (vospitanie) in their families (Bashieva 2012). However, unlike the Moscow State University studies' results, the low level of knowledge of the Circassian language did not create any alarm at the Kabardino-Balkarian government's Expert-Consultative Council for Preservation and Development of Languages of Native People of Kabardino-Balkaria, where the visepresident of KBSU stated, "Our academic researches over years into the problems of functioning of the state languages in KabardinoBalkaria allow us state that the language situation in KabardinoBalkaria is not critical, not at a crisis point, and not dramatic" (Bashieva 2012).

The regional language policy is based policy on the local constitutions and special regional laws that set out the language policy. In the case of the Circassian language, the regional constitutions regulate the language policy - the Constitution of Adygea (1995), the Constitution of Karachay-Cherkessia (1996), and the Constitution of Kabardino-Balkaria (1997). The special laws on language include Law on Languages of the Peoples of Adygea (1994), Law on Languages of the Peoples of Kabardino-Balkaria Republic (1995), Law on Languages of the Peoples of Karachay-Cherkessia 
(1996). According to the Constitution of the Russian Federation, the republics of the Russian Federation have the right to establish their own state language. All republics (except Karelia) have taken advantage of that right to some extent. In the case of the Circassian language, it is the state language of three (out of six) regions with Circassian population - in Adygea (with Russian), Kabardino-Balkaria (with Russian and Balkar), and Karachay-Cherkessia (with Russian and Karachay). The regions with indigenous Circassian population that have not established the Circassian language as a state language include North Ossetia, Stavropol Krai, and Krasnodar Krai.

The law 'On the Languages of Kabardino-Balkaria' (Law on Languages in the KBR) has undergone changes that are characteristic of a policy of decreasing the role of Circassian language. Here is the comparison of the original 1994 law with 2003 changes (Law on Languages 1995; Zakon KBR 2003). In the Law on Languages in the KBR, the expression 'state languages' (gosudarstvennye yazyki) was changed to 'languages of peoples' (yazyki narodov). Such a change did not have legal meaning, since local languages were granted state status by the Constitution. However, the deletion of the term 'state language' changed the context of this document by separating the local "peoples' languages" from the Russian language, which enjoyed the state support. The same way, new amendments in the Law on Languages in the KBR replaced the names of the titular languages. For example, at the very beginning, the sentence "The main goal of this law is the revival, preservation, and development of Kabardian and Balkar languages" was changed to "The main goal of this law is the preservation, and development of the languages of peoples of Kabardino-Balkaria."

The new editions of the law deleted one of the key terms, the expression 'language sovereignty.' The new version omitted the first article, which used to have the title 'Language Sovereignty and Individual Rights' (Yazykovoi suverenitet I prava lichnosti). The deleted article stated, "1- Language sovereignty is a unity of rights of peoples and individuals for the preservation and general development of their native language, for freedom of choice and usage of language of communication. 2- On the territory of Kabardino-Balkaria, in accordance with the Universal Declaration of Human Rights, the 
language sovereignty is guaranteed for all ethnic groups."

Articles 7 and 8 have undergone the most important changes and edits. The new amendments introduced the term "choice" from the Russian Constitution that was not in the law at the beginning. The title of Article 7, 'Language of Instruction and Education' (Yazyk vospitaniia $i$ obucheniia) was changed to "Right to Choose the Language of Instruction and Education' (Pravo vybora yazyka vospitaniia i obucheniia). This change came as the result of a wide discussion initiated by the Russian and local authorities looking into whether studying non-Russian languages in schools should not be mandatory, but only by choice. Russian language, however, remained mandatory (Tikaeva 2014). The most crucial change took place in Article 8. One of the sections of the Article 8 used to state: "In educational institutions (public schools from the first grade, elementary, secondary, high professional educational institutions) where Russian is the language of education, teaching the language of one of the indigenous peoples (Kabardian or Balkar) as one of the state languages of the republic is mandatory." That sentence was the core of the document; it declared that everybody should be able to study his or her native language. However, the legislators replaced it with a sentence that had no meaning, "the teaching of languages of peoples of the republic is conducted according to the laws of Kabardino-Balkaria on education."

The procedure of writing Master's and PhD theses in native language at local universities was also amended in the Law. The original version used to read, "Kabardino-Balkarian Republic guarantees the right to present and defend academic research in state languages for obtaining academic degrees." That comprehensible law had provided one of the authors of this article with the opportunity to write and defend his master's thesis in his native (Circassian) language in 1992 at the Kabardino-Balkarian State University. It was rather an unusual practice even then, however. As soon as his supervisor, Prof. Galim Mambetov, took responsibility for the research, it became much easier to present the master's thesis for defense. Parts of the thesis were later published in a local Circassian language daily newspaper; the main research was later accepted for publication in a collection of academic articles (Pschiby 1994; Zhemukhue 1994; Zhemukhue 2009, 177-196). 
Later, however, the local parliament replaced that clear statement with rather irrelevant edits: "The Republic of Kabardino-Balkaria creates conditions for academic research of the languages of peoples of the republic." The new version of the law denied local students and scholars the opportunity to defend their thesis in their native language. As it is formulated now, the law allows only conducting research about the Circassian language, but not submitting academic works written in Circassian. As a result, the state dramatically decreased support for students studying Circassian language at the local state-owned university. Dr. Madina Khakuasheva, a local activist for the development of the Circassian language in education, notes that the situation in her republic worsened even in comparison to the Soviet times - the quota of state sponsored students decreased from 75 in late Soviet time to 38 in the post-Soviet period. Khakuasheva also argues that nobody in the republic ever defended a doctorate in the Circassian language, and even the dissertations about the Circassian language are written and defended in Russian (Khakuasheva 2013).

In 2014, the parliament of Kabardino-Balkaria adopted a new law on education (Zakon ob obrazovanii). The new law alarmed local scholars, teachers, and civil right activists, and they unsuccessfully tried to stop the ongoing language reform. During the time when the parliament was working on the new law, local scholars separately organized several academic panels and offered about 80 edits to the new law. However, the parliament ignored those edits. In response, about 3500 people singed a letter of protest about the new law. A group of scholars and activists also wrote an "open letter" to the head of the republic, which stated, "The new law will decrease several times the number of those who study Kabardian and Balkar state languages and become the most significant step toward narrowing their cultural space since the Khrushchev's language reform in 1960s... We have no doubts that those individuals connected with the Law on Education will be written into the black page of the history of Kabardino-Balkaria" (Khakuashev 2014).

Another language initiative is concerned with changing of the Cyrillic script into Roman (Kumakhov 2006, 695-698). Such a project has pros and cons. This initiative is based on several arguments. Firstly, Roman script is supposed to help Circassians in diaspora to learn the 
language. Today, most of the Circassian population lives in diaspora outside of Russia. An estimated several million Circassians live in Turkey, while significant Circassian populations are also found in Syria, Jordan, USA, EU, and other countries. Owing to the lack of education infrastructure, most of the Circassian diaspora has been illiterate in Circassian until recently. Efforts have been made in the diaspora communities to develop a better education infrastructure for teaching Circassian language. The existing Cyrillic-based Circassian alphabet, however, is regarded as an additional obstacle for the development of literacy among Circassians outside of their homeland. Several alphabets have been designed in different diaspora communities, including ones devised by Batıray Özbek-Yediç, Muhadin Kandur, and Yılmaz Yemuz. Many view the change from Cyrillic to Roman script as helpful for the preservation of the language in the diaspora and also for bringing closer Circassians in the homeland and diaspora. The imbalance of the Circassian population in Russia and abroad is an additional argument for the supporters of the Roman script who argue that since most Circassians live in Turkey and use Romanized Turkish alphabet, it would make sense to devise a united Circassian alphabet based on Roman characters. Though the number of the Circassians in Turkey is unknown, the estimates vary from three to seven million against the 714,845-strong Circassian population in Russia (according to the 2010 census). Secondly, the fact that a Circassian alphabet based on Roman script did once exist encourages many activists to advocate a return to Roman script once again. Third, changing to a Roman script is supposed to buttress efforts for the unification of Eastern and Western Circassian alphabets. Changing the script, however, has its disadvantages. Most importantly, most of the existing Circassian literature has developed on the Cyrillic alphabet. The mere reprinting of existing Circassian texts in a different alphabet would require significant recourses that neither homeland Circassians nor diaspora Circassians possess.

Thanks to the existing education infrastructure in the homeland, most Circassians in Russia are literate, whilst majority in the diaspora are illiterate in the Circassian language. So far, the diaspora lacks the resources to build a sufficient education infrastructure to educate everybody. At the same time, the example of countries that recently 
changed their alphabets, like Azerbaijan, shows that such a language reform turns the older generation into an illiterate population. Thus, one might conclude that at the very beginning of a language reform, there would be no Circassians left who are literate in their language.

\section{Conclusion}

The Soviet Union was founded in 1922 on the basis of institutionalized multiethnic diversity in a way that was unprecedented and seemingly progressive for its time. However, this institutional heritage and policies went through at least four critical turning points that are analyzed in the first two sections of this article. These turning points started with Stalin's revisions in 1934, continued with Khrushchev's education reforms in 1959, and decisively turned toward assimilation with Yeltsin's passport reform in 1997 and Putin's various policies that followed up on the assimilationist course charted by Yeltsin. The modern Russian state policy has "shifted" toward assimilationist nation-building model where ethnic diversity is just a cultural, folkloric feature of an otherwise monolingual and monocultural nation-state.

Post-Soviet Russia has adopted a constitution that has established a clear distinction between the Russian language, as the native language of the Russian people, and the languages of the non-Russian ethnic groups. That distinction has become the main point of contemporary Russia's institutionalized multi-nationalist ideology and discriminative language policy. Federal and regional laws and policy practices favor Russian over the other titular languages of the indigenous peoples in the Russian Federation. However, the question remains; what is the purpose of such a discriminative ethnic and language policy? The study of the Circassian case has showed that so far such a policy has only caused political and cultural damages to all parties involved and has not produced any positive results. On the one hand, the assimilationist language policy continues to cause problems with the non-Russian ethnic groups, compounding the major challenges the Russian state is facing today. On the other hand, Circassians and other non-Russian ethnic groups struggle with an ineffective language policy and an education system that puts their languages on the brink of extinction. 


\section{BIBLIOGRAPHY}

AKTÜRK, Ş. 2009. "Persistence of the Islamic Millet as an Ottoman Legacy: Mono-Religious and Anti-Ethnic Definition of Turkish Nationhood." Middle Eastern Studies, 45/6, 893-909.

AKTÜRK, Ş. 2010. "Passport Identification and Nation-Building in PostSoviet Russia." Post-Soviet Affairs, 26/4, 314-341.

AKTÜRK, Ş. 2013. "The Four Pillars of Ottoman Identity: Religious Toleration, Diversity and the Four Millets under the 'Eternal State'." Turkish Review, 3/1, 16-23.

AKTÜRK, Ş. 2012. Regimes of Ethnicity and Nationhood in Germany, Russia, and Turkey. Cambridge: Cambridge University Press.

ARUTYUNOV, S.A. 2014. "Three Women's View on Circassian People (review)." Bulletin of the Institute for Humanities Research of the KBSC of RAN, 22, 88-95. http://www.kbigi.ru/fmedia/izdat/ vestnik/2014/ vestnik_2014_3(22).pdf (last accessed September 3, 2015).

BAKU, K.I. 2014. "Adygebzer: Dyguase, Nobe, Pshedei." Bulletin of the Institute for Humanities Research of the KBSC Of The RAN, 21, 69-80. (In Circassian language.)

BALABAS, E. 2015. "Viktor Sadovnishii: My Teriaem Kavkaz." Moskovskii Komsomolets, http://www.mk.ru/social/2015/07/17/ viktor-sadovnichiymy-teryaem-kavkaz.html (last accessed September 3, 2015).

BASHIEVA, S. 2014. "Provedenie Yazykovoi Politiki Kakimi-to Radikalnymi Metodami, Prinuzhdeniem Ne Dostignet Tseli." KabardinoBalkarskaia Pravda, http://kbpravda .ru/2014/04/12.pdf (last accessed September 3, 2015).

BELOV, S.A. 2015. "International Experience in Regulating the Legal Status of a State Language." Linguistic and Legal Aspects of the Text of the Federal Law on the State Language of the Russian Federation. SaintPetersburg State University, 124-139. http://rusgos.spbu.ru/index.php/article/english (last accessed September 3, 2015).

BILINSKY, Y. 1962. "The Soviet Education Laws of 1958-1959 and Soviet Nationality Policy." Europe-Asia Studies, 14/2, 138-157.

BOURDIEU, P. 1973. "The Algerian Subproletariat", in I. W. Zartman (ed.). Man, State, and Society In The Contemporary Maghreb. London: Pall Mall, 83-89.

BRUBAKER, R. 1994. "Nationhood and the National Question in the Soviet Union and Post-Soviet Eurasia: An Institutionalist Account," Theory and Society, 23, 47-78.

BULLOUGH, O. 2010. Let Our Fame Be Great: Journeys Among the Defiant People of the Caucasus. New York: Basic Books. 
CHUKOVSKY, K.I. 2003. Dnevnik. 1901-1969, 2, Moscow: Olma-Press Zvyozdnyi Mir.

Constitutional Court of Russia. 2005. "Decision of the Constitutional Court of Russia from November 16, 2004, no. 16-P." Vestnik Konstitutsionnogo Suda, no.1.

DERLUGUIAN, G. 2005. Bourdieu's Secret Admirer in the Caucasus: A World-System Biography. Chicago: University of Chicago Press.

DUNLOP, J. 1998. Russia Confronts Chechnya: Roots of a Separatist Conflict. New York: Cambridge University Press.

Federalnyi Zakon. 1999. O Garantiyakh Prav Korennykh Malochislennykh Narodov Rossiiskoi Federatsii, Moscow, http://www.minnac.ru/minnac/info/13883.html (last accessed September 31, 2015)

Federalnyi Zakon. 2005. O Gosudarstvennom Yazyke Rossiiskoi Federatsii, Moscow, http://rus-gos.spbu.ru/index.php/bills/ (last accessed September 3, 2015)

Federalnyi Zakon. 2015. "O Vnesenii Izmenenii v Federalnyi Zakon 'O Gosudarstvennoi Politike RF v Ontoshenii Sootechestvennikov za Rubezhom." Rossiiskaya Gazeta, http://www.rg.ru/2010/07/27/sootechdok.html (last accessed September 3, 2015).

FEDOROVA, T.S. 2015. "Russia. Profile." Compendium of Cultural Policies and Trends in Europe. Council of Europe/ERICarts, 16th edition, http://www.culturalpolicies.net/ web/russia. . php?aid=519\&cid=1390\&curl=425 (Last accessed September 3, 2015)

GOULD, R. 2010. "Language Dreamers: Race and the Politics of Etymology in the Caucasus," in Grant and Yalçın-Heckmann (eds.). Caucasus Paradigms: Anthropologies, Histories, and the Making of a World Area. Halle Studies in the Anthropology of Eurasia, 13, 143-166.

GRANT, B. 2009. The Captive and the Gift: Cultural Histories of Sovereignty in Russia and the Caucasus. Ithaca, NY: Cornell University Press.

HALE, H. 2005. Why Not Parties in Russia? Democracy, Federalism, and the State. New York: Cambridge University Press.

HANSON, S.E. 2010. Post-Imperial Democracies: Ideology and Party Formation in Third Republic France, Weimer Germany, and Post-Soviet Russia. New York: Cambridge University Press.

HIRSCH, F. 2005. Empire of Nations: Ethnographic Knowledge and the Making of the Soviet Union. Cornell University Press.

KHAKUASHEV, A. et al. 2014. "Open Letter to the Head of KabardinoBalkariiaon April 8, 2014." Kabardino-Balkarskii Pravozashitnyi Tsentr. http://zapravakbr.ru/index.php?option= 
com_content\&view=article\&id=451:2013-08-06-10-2430\&catid $=5$ :

analinic\&ltemid=7 (last accessed July 31, 2015, the website does not work anymore).

KHAKUASHEVA, M. 2015. "Problema Sokhraneniia KabardinoCherkesskogo Yazyka. Istoriia I Sovremennost." Kabardino-Balkarskii Pravozashitnyi Tsentr. http://zapravakbr.ru/ index.php?option =com_content\&view=article\&id=451:2013-08-06-10-2430\& catid=5:analinic\&Itemid=7 (last accessed July 31, 2015, the website does not work anymore).

KING, C. 2010. The Ghost of Freedom: A History of the Caucasus. New York: Oxford University Press.

KUMAKHOV M.A. 1981. Sravnitel'no-Istoricheskaia Grammatika Adygskikh (Cherkesskikh) Literaturnykh Yazykov. Moscow: Nauka.

KUMAKHOV, M.A. (ed.) 2006. Adygskaia (Cherkesskaia) Entsiklopediia. Moscow: Fond B. Akbasheva, 695-698.

KUMAKHOVA, Z.Y. 1972. Razvitie Adygskikh Literaturnykh Yazykov. Moscow: Nauka.

LARUELLE, M. 2015. "Eurasia, Eurasianism, Eurasian Union: Terminological Gaps and Overlaps." PONARS Eurasia, 366, http://www.ponarseurasia.org/memo/eurasia-eurasianism-euras ianunion-terminological-gaps-and-overlaps (last accessed September 3, 2015).

Law Languages of the Peoples of Kabardino-Balkaria Republic (1995). Kavkazskii Uzel, October 3, 2001 http://www.kavkaz-uzel.ru/articles/9945/ (last accessed September 3, 2015).

Law on Languages of the Peoples of Adygea (1994). http://rusgos.spbu.ru/public/files/bills/Адыгея_zakon53915fd995a 2f.pdf (last accessed September 3, 2015).

Law on Languages of the Peoples of Kabardino-Balkaria Republic (1995 with revisions). http://rus-gos.spbu.ru/public/files/bills/6_ 5391b88745115.pdf (last accessed September 3, 2015).

Law on Languages of the Peoples of Karachay-Cherkesia (1996), http://rusgos.spbu.ru/public/files/bills/8_5391b95f38dc0.pdf

(last accessed September 3, 2015).

LAYTON, S. 2005. Russian Literature and Empire: Conquest of the Caucasus from Pushkin to Tolstoy. New York: Cambridge University Press.

LIEVEN, A. 1998. Chechnya, the Tombstone of Russian Power. New Haven: Yale University Press.

LUNACHARSKY, A. 1930. "Latinizatsiia Russkoi Pis'mennosti," Kul'tura I Pis'mennost' Vostoka, 6, 20-26.

MALBAKHOV, T. 2008. Rechi. Stat'i. Pis'ma. Nalchik: El-Fa. 
MARTIN, T.D. 2001. The Affirmative Action Empire: Nations and Nationalism in The Soviet Union, 1923-1939. Cornell University Press.

MCCONNELL, G.D, SOLNTSEV, V.M. \& MIKHALCHENKO, V.I. (eds.). 2000. Pismennye Yazyki Mira. Yazyki Rossiskoi Federatsii L Sotsiolingvisticheskaya Entsiklopediya. Kniga 1. Moscow: Institut Yazakoznaniya RAN, 52, 164. http://web.archive.org/web/

20061206082941/http://www.auditorium.ru/books/1478/r9.pdf (last accessed September 3, 2015).

MOROZOV, V. 2015. "Kazakhstan and the "Russian World": Is a New Intervention on the Horizon?" PONARS Eurasia, 364. http://www.ponarseurasia.org/memo/kazakhstan-and-russian-world-newintervention-horizon (last accessed September 3, 2015).

NEKRICH, A.M. 1981. The Punished Peoples: The Deportation and Fate of Soviet Minorities at the End of the Second World War. W. W. Norton \& Company.

NEVEZHIN, V.A. 2010. "Tost Stalina, 'Za Russkii Narod' (24 Maya 1945)." Mir i Politika, 44, 92-99.

PLATT, K.M.F, \& BRANDENBERGER, D. (eds.). 2006. Epic Revisionism: Russian History and Literature as Stalinist Propaganda. University of Wisconsin Press.

Postanovlenie "o Likvidatsii Bezgramotnosti Sredi Naselenia RSFSR (Instruktsiya)." 1920. Moscow: Narodny Komissariat Prosveshetiya, Istorichskiye Materialy. http://istmat.info/node/ 40942 (last accessed September 3, 2015).

Postanovlenie Parlamenta KBR. 2014. Ob Obrashenii Parlamenta KBR K Predsedatelyu Pravitelstva RF D.A. Medvedevu po Voprosu Vklyucheniaya Naroda Ubykhi v Edinyi Perechen Korennykh Malochislennykh Narodov RF. Nalchik, http://monitoring.zspk. gov.ru/файл/1133984/3272-pdf (last accessed September 3, 2015).

PSCHIBY, I. 1994. "Myschem I Shher Plhaghume," Adyge Psalhe. (In Circassian language.)

PUTIN, V.V. 2015. "The Speech at the Council for Interethnic Relations and the Council for the Russian Language on 19 May 2015." President of Russia. http://en.kremlin.ru/events/president/ news/49491 (Last visited July 31, 2015).

RICHMOND, W. 2013. The Circassian Genocide. Rutgers University Press.

SCOTT, J.C. 1998. Seeing Like a State: How Certain Schemes to Improve the Human Condition Have Failed. Yale University Press.

SLEZKINE, Y. 1994. "The USSR as a Communal Apartment, or How a Socialist State Promoted Ethnic Particularism." Slavic Review, 53/2, 414452. 
STARODUBROVSKAIA, I.V. (ed.). 2012. Severnyi Kavkaz: Modernizatsionnyi Vyzov. Moscow: Delo.

The Constitution of the Russian Federation (1993).

TIKAEVA, F. 2014. "Zakon Pretknoveniia." Kavpolit, http://kavpolit.com/articles/zakon_pretknovenija-2023/ (last accessed September 3, 2015).

TIMASHEFF, N.S. 1946. The Great Retreat: The Growth and Decline of Communism in Russia. EP Dutton \& Company, Inc..

TIMIZHEV, K. 2014. "Problemy Normativnogo Obestpecheniia Funktsionirovaniia Fosudarstvennykh Yazykov KBR." Osobennosti Funktsionirovaniia Gosudarstvennykh Yazykov $V$ Bilingvalnoy Srede. Nakchik.

TISHKOV, V. 1997. Ethnicity, Nationalism and Conflict in and after the Soviet Union: The Mind Aflame. Oslo: PRIO, 246-271.

TROTSKY, L. 1937. The Revolution Betrayed: What is the Soviet Union and Where is it Going?, Mehring Books.

TSUTSIEV, A. 2013. Atlas of the Ethno-Political History of the Caucasus. Translated by Nora Seligman Favorov. New Haven: Yale University Press.

URBAN, M., V. Igrunov, S. Mitrokhin. 1997. The Rebirth of Politics in Russia. Cambridge: Cambridge University Press.

Vserossiiskaia Perepis Naseleniaia 2010, 4, 9-21, 142-143. http://www.gks.ru/free_doc/new_site/perepis2010/croc/Documents/Vol4/ pub-04-01.pdf; www.gks.ru/free_doc/new_site/perepis2010/ croc/Documents/Vol4/pub-04-05.pdf (last accessed September 3, 2015).

WIXMAN, R. 1980. Language Aspects of Ethnic Patterns and Processes in the North Caucasus, University of Chicago Geography Research Series, 19.

ZAKON KBR. "O Vnesenii Izmenemii I Dopolnenii V Zakon KBR "O Yazykakh Narodov KBR"." Parlament KBR, February 20, 2003. http://www.rusouth.info/territory6/pack4z/paper-hfgnx0.htm(last accessed September 3, 2015).

ZHEMUKHOV S. 2009. "Pasche Bechmyrze Ts'ykhu Hetych'em Zereplhu Schytar." In Karmoque and Pschiby (eds.). Pasche Bechmyrze; I Ghasch'emre I Lezh'yghemre. Nalchik, Russia: Elbrus, 177-96. (In Circassian language.)

ZHEMUKHOV, S. 1994. "Pasche Bechmyrzere Istembylak'uemre Tewyhwawe ljyri Ze," Adyge Psalhe. (In Circassian language.)

ZHEMUKHOV, S. 2011. "One Thousand Years of Islam in Kabarda: An Experiment in Periodization," Anthropology \& Archaeology of Eurasia, 49/4, 54-71.

ZHEMUKHOV, S. 2012. "The Birth of Modern Circassian Nationalism," Nationalities Papers, 40/4, 503-524. 
Sufian Zhemukhov - Şener Aktürk 